Discussion Paper No. 10-002

Corporate Governance and Current Regulation in the German Banking Sector: An Overview and Assessment

Matthias Köhler

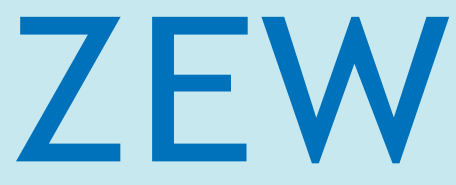

Zentrum für Europäische Wirtschaftsforschung $\mathrm{GmbH}$ Centre for European Economic Research 
Discussion Paper No. 10-002

\title{
Corporate Governance and Current Regulation in the German Banking Sector: An Overview and Assessment
}

\author{
Matthias Köhler
}

Download this ZEW Discussion Paper from our ftp server:

ftp://ftp.zew.de/pub/zew-docs/dp/dp10002.pdf

Die Discussion Papers dienen einer möglichst schnellen Verbreitung von neueren Forschungsarbeiten des ZEW. Die Beiträge liegen in alleiniger Verantwortung der Autoren und stellen nicht notwendigerweise die Meinung des ZEW dar.

Discussion Papers are intended to make results of ZEW research promptly available to other economists in order to encourage discussion and suggestions for revisions. The authors are solely responsible for the contents which do not necessarily represent the opinion of the ZEW. 


\section{Non-Technical Summary}

The recent financial crisis has put the German banking sector under enormous pressure. Besides the macroeconomic drivers like, for example, the expansionary monetary policy in major countries, insufficient risk management and weak corporate governance systems have been identified as the main reasons for the financial crisis.

In Germany, corporate governance is weakened by the three-pillar structure of the German banking system that reduces the power of market for corporate control. Furthermore, the large ownership stake of the government in the German banking sector weakens corporate governance, since government officials may have other interests than private shareholders and may be less motivated to monitor the management. Politicians may also be less educated and experienced to fulfil their role as monitor of bank managers. This corresponds to the results of a recent OECD report on corporate governance in the financial sector (Kirkpatrick, 2009). The report identifies adverse incentives created by remuneration schemes together with insufficient monitoring by the supervisory board as one of the main reasons for the financial crisis.

To improve corporate governance the German government has started several initiatives in the past two years. They mainly focus on improving the risk management of banks, on reducing the incentives for managers to increase short-term profits created by remuneration schemes and on further professionalizing the supervisory board. To reduce the incentives to take large risks, remuneration schemes for managers must, for example, in future be geared toward long-term performance and also reflect negative business trends, while the supervisory board must, henceforth, include at least one person that has the required knowledge, abilities and expert experience to properly fulfil his monitoring tasks. This should particularly improve corporate governance in the public sector where members of the supervisory boards are often based on their political affiliation and not based on their experience and skills.

Problematic is that several laws that were enacted in the past years to improve corporate governance focus on listed firms. Furthermore, the recommendations and suggestions made by the German Corporate Governance Code are not legally binding even for stock corporations. In particular, most Landesbanken have so far abstained from applying the code and enacted their own corporate governance guidelines. This reduces the comparability and transparency of corporate governance standards in particular in those banks that have shown the biggest corporate governance problems during the recent financial crisis. Recent empirical evidence, moreover, suggests that shareholders pushed for greater risk-taking and not managers. This contrast with public view that the bank managers are pushed by aggressive remunerations schemes to increase risk-taking. This indicates that the recent legal and regulatory changes fail to remove all weaknesses of the German corporate governance system. 


\section{Das Wichtigste in Kürze}

Die aktuelle Finanzmarktkrise hat das deutsche Bankensystem stark unter Druck gesetzt. Neben der expansiven Geldpolitik werden vor allem ein unzureichendes Risikomanagement und mangelnde Corporate Governance im Bankensektor für die Krise verantwortlich gemacht.

In Deutschland wird die Corporate Governance im Bankensektor durch die 3Säulenstruktur des deutschen Bankensystems geschwächt, die eine feindliche Übernahme praktisch unmöglich macht. Darüber hinaus wirkt sich der große Einfluss der öffentlichen Hand negativ auf die Corporate Governance in deutschen Banken aus, da Politiker andere Ziele haben und weniger motiviert sein könnten, das Management der Bank zu kontrollieren, als Privatpersonen. Das stimmt mit den Ergebnissen einer Studie der OECD (Kirkpatrick, 2009) überein, nach der falsche Vergütungssysteme für Manager und mangelnde Kontrolle durch den Aufsichtsrat die Hauptgründe für die Finanzmarktkrise sind.

Die Bundesregierung hat in denn vergangenen zwei Jahren mehrere Initiativen gestartet, um die Corporate Governance bei Banken zu verbessern. Sie konzentrieren sich überwiegend auf die Vergütung von Managern und auf die Stärkung des Aufsichtsrats. Um den Anreiz zur Steigerung kurzfristiger Gewinne zu reduzieren, soll die Managerentlohnung zum Beispiel künftig verstärkt die langfristige Entwicklung berücksichtigen und auch negative Geschäftsentwicklungen widerspiegeln. Der Aufsichtsrat soll in Zukunft hingegen mindestens einen Finanzexperten enthalten, damit er seine Kontrollfunktion besser ausüben kann. Das sollte insbesondere die Corporate Governance bei den öffentlichen Banken stärken, da die Mitglieder des Aufsichtsrats von Unternehmen im öffentlichen Sektor häufig nicht anhand ihrer Qualifikation und ihrer Erfahrung, sondern anhand ihres Parteibuchs ausgewählt werden.

Problematisch ist, dass viele der Gesetze, die in den vergangenen Jahren zur Stärkung der Corporate Governance verabschiedet wurden, nur für börsennotierte Unternehmen gelten. Darüber hinaus ist der Deutschen Corporate Governance Kodex selbst für börsennotierte Unternehmen nicht gesetzlich verpflichtend. Insbesondere die Landesbanken haben bisher davon abgesehen, den Kodex anzuwenden und anstatt dessen eigene Standards eingeführt. Das reduziert die Vergleichbarkeit und die Transparenz von Corporate Governance Standards insbesondere bei den Banken, die die größten Corporate Governance Probleme in der Krise gezeigt haben. Aktuelle Studien für den Bankensektor deuten darüber hinaus darauf hin, dass nicht die Manager, sondern die Aktionäre ein hohes Risiko eingehen wollten. Das widerspricht der öffentlichen Meinung, dass die Manager deutscher Banken durch aggressive Vergütungssysteme verleitet wurden, hohe Risiken einzugehen. Daran wird auch deutlich, dass die aktuellen gesetzlichen und regulatorischen Änderungen nicht alle Schwächen des deutschen Corporate Governance Systems beseitigt haben. 


\title{
Corporate Governance and Current Regulation in the German Banking Sector: An Overview and Assessment
}

\author{
Matthias Köhler \\ Zentrum für Europäische Wirtschaftsforschung (ZEW)
}

January 2010

\begin{abstract}
This paper gives an overview over corporate governance and banking regulation in Germany. Particular attention is put on legal and regulatory changes that were made in response to the financial market crisis. The paper shows that the changes mainly focus on the remuneration of managers and on further professionalizing the supervisory board. Problematic is that several laws that were enacted in the past years to improve corporate governance focus on listed firms. Furthermore, some of the recommendations and suggestions made to improve corporate governance in Germany are not legally binding even for stock corporations. Recent empirical evidence, moreover, suggests that bank shareholders pushed for greater risk-taking and not managers. This contrast with public view that the bank managers are pushed by aggressive remunerations schemes to increase risk-taking and indicates that the recent legal and regulatory changes fail to remove all weaknesses of the German corporate governance system.
\end{abstract}

Keywords: Corporate governance, banks, regulation, remuneration schemes, supervisory board

JEL-Classification: G21, G34, G38

L 7, 1

Postfach 103443

D-68034 Mannheim
Tel.: $\quad 0621 / 1235-148$

Fax: $\quad 0621 / 1235-223$

E-mail: koehler@zew.de 


\section{Introduction}

The recent financial crisis has put the German banking sector under enormous pressure. Banks had to massively write-down bad loans and needed large capital injections to offset their existing write-downs and to prevent a systemic collapse of the German banking system. Further write-offs are expected in the future. The Deutsche Bundesbank (2009a), for example, estimates that German banks have to make further write-off in the range between 50 and 75 billion euros up to the end of 2010. Besides the macroeconomic drivers like, for instance, the expansionary monetary policy in major countries, insufficient risk management and weak corporate governance systems are deemed the main reasons for the crisis according to the OECD (Kirkpatrick, 2009). In particular, adverse incentives created by remuneration schemes and insufficient monitoring by the supervisory board are regarded as the main microeconomic drivers of the crisis.

This study analyzes the corporate governance systems in the German banking sector and provides an overview over and an assessment of recent changes in corporate governance and banking regulation. In the next section, I give a brief overview over the German banking system, before I focus on the systems of corporate governance in German banks in Section 3. Section 4 concentrates on the role of the supervisory board as internal corporate governance mechanism, while Section 5 briefly describes corporate governance legislation in Germany up to 2007. Since weak corporate governance systems have been identified as one of the main reasons for the recent financial crisis, Section 6 gives a brief overview over the initiatives that were started by the German government in 2008 and 2009 to improve corporate governance in Germany. For an overview over the main anti-crisis measures of the German government see Box 1. Section 7 concludes.

\section{Overview over the German Banking Sector}

The German banking system is a three-pillar system comprising commercial banks, savings ('Sparkassen') and cooperative banks ('Genossenschaftsbanken'). The distinction between these types of banks is made based on the legal form of these institutions. While commercial banks are governed by private law and operate nationwide, savings banks are governed by public law. Since savings banks are owned by municipalities or counties, their business area is locally or regionally restricted. Cooperative banks operate on a regional basis as well. They are owned by their customers and follow the cooperative principle according to which one person has only one vote independent of the number of shares he owns. 


\section{Box 1: Main Legal and Regulatory Changes in Response to the Financial Crisis}

In response to the financial crisis several initiatives were started to improve corporate governance in Germany. They mainly focus on:

- Management Compensation and the

- Supervisory Board

\section{1) Management Compensation}

To reduce the incentives for managers to increase short-term profits the following changes have been made:

- Reform of the German Corporate Governance Code (in force since 18.06.2009)

- recommends that the management board should manage the enterprise with the objective of sustainable creation of value and in the interest of the enterprise and its stakeholders.

- recommends that management compensation should be appropriate in terms of personal performance, the performance of the enterprise and the common level of compensation in the industry

- recommends that the supervisory board makes sure that the variable compensation elements are based on a multi-year assessment with positive and negative developments be taken into account

- New Minimum Requirements for Risk Management (MaRisk) (to be implemented by 31.12.2009)

- requires that the variable compensation for staff members in risk-relevant positions should take due account of the risk taken

- stipulates that the level of the variable compensation should also reflect negative business trends

- Law on the Appropriateness of Executive Remuneration (VorstAG) (in force since 5.08.2009)

- requires that management compensation should be appropriate in terms of personal performance and the common level of compensation in the industry/country

- stipulates that the variable compensation components should be based on a multi-year assessment

- requires that managers are allowed to use their stock options at the earliest four years after they were granted

- increases the disclosure requirements for management compensation further to improve transparency

- the general meeting of stock corporations can, henceforth, make a non-binding vote on management compensation

\section{2) Supervisory Board}

The following legal and regulatory changes have been made to further professionalize the supervisory board:

- Reform of the German Corporate Governance Code (in force since 18.06.2009)

- recommends that the full supervisory board determines the total compensation of the management board

- recommends that the chairman of the audit committee shall be a financial expert

- New Minimum Requirements for Risk Management (MaRisk) (to be implemented by 31.12.2009)

- makes a remuneration committee mandatory for banks

- requires that the management board reports the supervisory board at least once a year on all severe problems that were identified during the internal audit and on all problems which have not yet been remedied

- Law on the Appropriateness of Executive Remuneration (VorstAG) (in force since 5.08.2009)

- requires that the decision on management compensation is made by the full supervisory board and not by a special committee

- increases the power of the supervisory board to reduce management compensation retroactively if the situation of the company deteriorates

- increases the liability of the supervisory board if management compensation is unreasonably high

- Accounting Law Reform Act (BilMoG) (in force since 29.05.2009)

- makes an audit committee mandatory for capital market oriented institutions

- requires that the audit committee includes at least one independent financial expert 
While the goal of commercial banks is profit maximization, savings banks and cooperative banks have social goals as well. Both savings banks and cooperative banks have central institutions that were originally founded for providing development financing in their regions and for acting as central banking institutions. In contrast to savings banks and cooperative banks, the central institutions operate nationwide and are less restricted in their business activities. This has become visible during the crisis, since the central institutions of the savings banks ('Landesbanken') recorded high losses owing to their activities on the international financial market. Besides commercial, savings and cooperative banks, the German banking sector also includes mortgage banks ('Realkreditinstitute') and building societies ('Bausparkassen') that operate in all three sectors of the banking system providing medium- and long-term credit secured against domestic real-estate. There are also several special purpose banks that promote economic and social development through lending, equity investment and technical assistance.

The importance of each of these banking groups is reflected in Figure 1. The first pillar of the German banking system comprises the group of commercial banks. This group includes the four large domestic banks that are commonly referred to as the 'Big Banks' ('Großbanken') as well as a number of smaller regional and other credit institutions. The four Großbanken are the Deutsche Bank, Commerzbank/Dresdner Bank, Hypovereinsbank and Postbank. Together with the smaller commercial banks they accounted for 29 percent of total banking sector assets in Germany in 2008. The second pillar comprises the savings banks and the Landesbanken. They had a market share of 34 percent in 2008. The cooperative banks and their central institutions constitute the third pillar of the German banking system. Together they owned 11 percent of total banking sector assets in 2008. Owing to the large market share of the savings banks and the Landesbanken as well as several special purpose banks which are either directly or indirectly owned by the federal or state government, government ownership in the banking is more important in Germany than in other developed countries. The influence of the state has increased further in the past two years as a result of the financial crisis. Commerzbank, for example, got a capital injection of almost 18 billion euros from the Financial Market Stabilization Fund (SoFFin) that has given the state a stake of 25 percent plus one share in Germany's second-biggest listed bank. Hypo-Real Estate has already been nationalized. 
Figure 1: Market Sh are of Different Bankin g Groups in the German Banking Sector (2008)

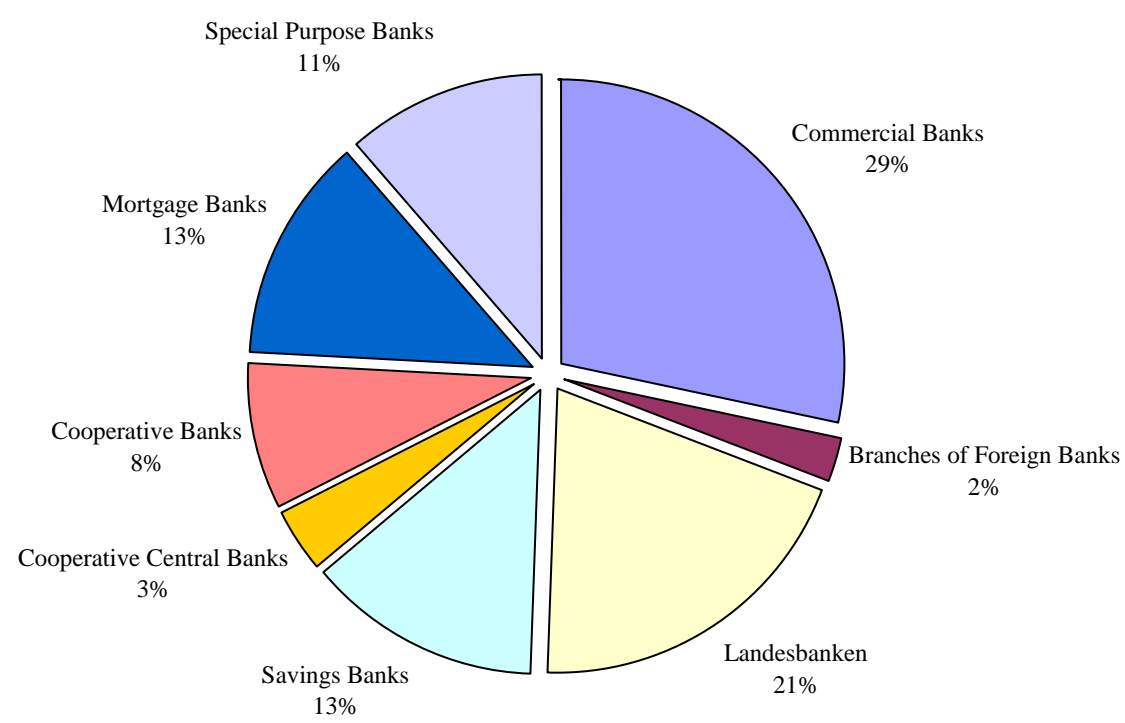

Source: Bundesbank (2009b). Note Figure 1 presents the market share of different banking groups in the German banking system. The market share equals the ratio of total assets that were held by each banking group divided by total banking sector assets in 2008 .

\section{Systems of Corporate Governance in the German Bank- ing Sector}

Corporate governance deals with principal-agent problems between managers and shareholders. Such problems arise because managers (agent) and shareholders (principal) have the incentive to maximize their personal utility (Jensen and Meckling, 1976). Since contracts cannot completely specify a priori what the management has to do with the money and how the returns are divided between him and the shareholders, managers have considerable scope to increase their utility to the detriment of the shareholders (Shleifer and Vishny, 1997). The corporate governance literature discusses different mechanisms to stop managers from increasing their utility. These mechanisms are broadly distinguished into internal and external devices for corporate control. While external corporate governance describes the links between the firm and its stakeholders and the general public, internal corporate governance mechanisms refer to the devices within the firm to reduce the principal-agent problem. ${ }^{1}$

For a survey on various internal and external corporate governance mechanisms see Shleifer and Vishny (1997). 
The market for corporate control is an external corporate governance mechanism. It disciplines the management, since poor performance increases the threat of a takeover and raises the probability that the incumbent managers loose their job (Manne, 1965). For this reason, Jensen and Ruback (1983) regard the takeover market as part of the managerial labour market on which different management teams compete for the rights of managing corporate resources. Owing to regulations on entry, mergers, takeovers and administrative rules the power of the market for corporate control to discipline the management is lower in the banking sector than in the non-financial sector (Prowse, 1995). The requirement that takeovers in the banking sector need approval by the supervisor, for example, considerably delays the acquisition process and makes hostile takeovers whose success typically depends on the ability to close the transaction quickly almost impossible in the banking sector (Prowse, 1995). ${ }^{2}$ Takeovers are also limited by restrictions that limit ownership in certain types of banks. In Germany, for example, savings banks are not allowed to be taken over by commercial banks. Only acquisitions within the savings banks sector are allowed. In the cooperative sector, takeover activity is limited by the cooperative principal of one person-one vote that makes acquisitions virtually impossible. This suggests that the three-pillar structure considerably restricts the power of the market for corporate control in the German banking sector

Outside shareholders can discipline managers by monitoring their activities. However, given the information asymmetries between the management and the shareholders, each shareholder has to incur monitoring costs. For this reason, every shareholder will free-ride in the hope that other shareholders will do the monitoring (Jensen and Meckling, 1976). This leaves the management with considerable discretion to divert corporate resources for their private benefits (Jensen and Meckling, 1976). Since large shareholders have more voting rights and larger incentives to monitor the management than minority shareholders, they are better able to control the management then minority shareholders Shleifer and Vishny (1986, 1997). Large shareholders may also have access to superior information and be involved in the decision-making process by approving certain management decisions, since they usually have a seat on the board of directors, which is an internal governance mechanism. Board representation may be particularly important in the banking sector, since information asymmetries are larger in the banking sector than in other sectors of the economy (Levine, 2004).

2 Furthermore, the supervisory approval process is often used by politicians and supervisors to block specific transactions in the banking sector. Köhler (2009), for example, finds that cross-border mergers and acquisitions (M\&A) are significantly more likely in the EU banking sector if merger control is transparent and supervisors and politicians have less scope to block takeovers for opaque concerns. This corresponds to the results of a survey by the EU Commission (2005). The survey identifies the merger review process, the misuse of supervisory powers and political interference as an important barrier to cross-border consolidation in the EU financial sector. 
This makes monitoring more difficult and increases the scope of bank managers to extract private benefits. Information asymmetries may, hence, explain why banks are generally not widely (Caprio et al., 2007). However, ownership concentration may also come with some costs. Shleifer and Vishny $(1986,1997)$, for example, note that the interests of large shareholders may deviate form the interests of minority shareholders. It follows that concentrated ownership reduces the principal-agent problem between managers and minority shareholders, but creates a new agency problem between blockholders and minority shareholders. The latter should be particularly severe in small to medium-sized banks, while they should be less important for the largest German banks that usually have a more dispersed ownership structure owing to larger capital needs and cross-holdings with other banks.

Savings and cooperative banks are an exemption. While ownership in cooperative banks is widely dispersed owing to the cooperative principle that gives each shareholder only one vote, savings banks are usually fully owned by their municipality or the local government. The Landesbanken are, in contrast, jointly owned by their local savings banks and the federal states. As a result of the financial crisis the influence of the public sector in the German banking has further increased. This raises questions, since government participation in banks is usually found to not improve corporate governance in the banking sector because government officials may have other interests than private shareholders and may be less motivated to monitor the management. Politicians may also be less educated and experienced to fulfil their role as monitor of bank managers. Furthermore, the state faces a conflict of interest owing to his role as regulator and shareholder. If private shareholders speculate that banks are more likely to be bailed-out in a crisis, they may reduce their monitoring incentives. Together this may increase the scope of public bank managers to divert corporate resources for personal benefits. Finally, Shleifer and Vishny (1998) point out that politicians may use their power as bank shareholders to maximize their own personal objectives. Sapienza (2004), for example, finds that state-owned banks charge systematically lower interest rates in regions in which the political party affiliated with the bank is stronger. This suggests that government ownership weakens corporate governance in the German banking sector. The corporate governance problems may also explain the severe difficulties of the Landesbanken during the crisis. West $L B$, for example, faced serious problems that necessitated a rescue package by the German government in early 2008. In addition, many other public sector banks, including BayernLB, NordLB, HSH Nordbank, Sachsen $L B$ and $L B B W$, needed financial support from the German government. For a list of banks that benefited from the rescue programme see Table 1. 


\section{Board Composition and Board Structure}

Owing to intense regulation and large information asymmetries bank managers are mainly disciplined by internal governance mechanisms. One important internal governance mechanism is the board of directors. A specific feature of the German board system is that it has a two-tiered structure with a management ('Vorstand') and a supervisory board ('Aufsichtsrat' or 'Verwaltungsrat'). In this system, the management board is responsible for the operating business, while the task of the supervisory board is to appoint, to dismiss and to monitor the management. The members of the supervisory board are usually representatives of large shareholders. Owing to their representation on the supervisory board large shareholders have better access to information than minority shareholders. This may be particularly important in the banking sector in which information asymmetries are larger and may explain why ownership concentration is usually larger in the banking sector than in the non-financial sector (Caprio et al., 2007). Another distinguishing feature of the German board system is the system of co-determination that gives the employees a role in the management of the company. For listed firms with more than 2000 employees, the CoDetermination Act of 1976 has created a system of quasi-parity co-determination according to which employee representative make up half of the supervisory board. The chairman of the supervisory board, however, is a shareholder representative that has the casting vote in case of a stale-mate. In companies with less than 2000 employees, one third of the supervisory board has to consist of employee representatives.

To ensure the independence the supervisory board the German Corporate Governance Code recommends that only two former members of the management board are allowed to be members of the supervisory board. Furthermore, supervisory board members shall not exercise directorships or similar positions or advisory tasks for important competitors of their enterprise. To accomplish its duties, the German Corporate Governance Code recommends that the management periodically reports to the supervisory board on all important questions. The supervisory board shall, moreover, require the management to obtain its prior approval before entering into certain important transactions. To make it possible to deal with complex issues the supervisory board is recommended to form committees consisting of a smaller number of members with sufficient expertise. One of these committees should propose suitable candidates to the supervisory board for recommendation to the general meeting (nomination committee). Further committees should be formed that deal with subjects like the strategy of the enterprise, the compensation of the members of the management board (remuneration committee), investments and financing. The supervisory 
Table 1: Government Rescue Programme for the German Banking Sector

\begin{tabular}{|c|c|c|c|}
\hline Name of the Bank & $\begin{array}{c}\text { Amount } \\
\text { (in billion euros) }\end{array}$ & Measure & Institution \\
\hline \multirow[t]{2}{*}{ Aareal Bank } & 0.5 & Silent Participation & Financial Market Stabilization Fund (SoFFin) \\
\hline & 4.0 & Guarantee & Financial Market Stabilization Fund (SoFFin) \\
\hline \multirow[t]{3}{*}{ Bayerische Landesbank (Bayern LB) } & 10.0 & Equity Capital & Federal State of Bavaria \\
\hline & 4.8 & Guarantee & Federal State of Bavaria \\
\hline & 15.0 & Guarantee & Financial Market Stabilization Fund (SoFFin) \\
\hline \multirow[t]{3}{*}{ Commerzbank } & 15.0 & Guarantee & Financial Market Stabilization Fund (SoFFin) \\
\hline & 8.2 & Silent Participation & Financial Market Stabilization Fund (SoFFin) \\
\hline & 10.0 & Equity Capital & Financial Market Stabilization Fund (SoFFin) \\
\hline Düsseldorfer Hypothekenbank & 2.5 & Guarantee & Financial Market Stabilization Fund (SoFFin) \\
\hline \multirow[t]{3}{*}{ HSH Nordbank } & 30.0 & Guarantee & Financial Market Stabilization Fund (SoFFin) \\
\hline & 3.0 & Equity Capital & Federal State of Schleswig Holstein \& Hamburg \\
\hline & 10.0 & Guarantee & Federal State of Schleswig Holstein \& Hamburg \\
\hline \multirow[t]{2}{*}{ Hypo Real Estate } & 52.0 & Guarantee & Financial Market Stabilization Fund (SoFFin) \\
\hline & 3.0 & Equity Capital & Financial Market Stabilization Fund (SoFFin) \\
\hline IKB Deutsche Industriebank AG & 5.0 & Guarantee & Financial Market Stabilization Fund (SoFFin) \\
\hline \multirow[t]{2}{*}{ Landesbank Baden-Wuerttemberg (LBBW) } & 5.0 & Equity Capital & Federal State of Baden-Wuerttemberg and City of Stuttgart \\
\hline & 12.7 & Guarantee & Federal State of Baden-Wuerttemberg and City of Stuttgart \\
\hline Norddeutsche Landesbank (NordLB) & 20.0 & Guarantee & Federal States of Lower Saxony and Saxony-Anhalt. \\
\hline Sächsische Landesbank (SachsenLB) & 2.8 & Guarantee & Federal State of Saxony \\
\hline Volkswagenbank & 2.0 & Guarantee & Financial Market Stabilization Fund (SoFFin) \\
\hline \multirow[t]{2}{*}{ Westdeutsche Landesbank (WestLB) } & 3.0 & Silent Participation & Financial Market Stabilization Fund (SoFFin) \\
\hline & 9.0 & Guarantee & Federal State of North Rhine-Westphalia and local Savings Banks Association \\
\hline
\end{tabular}

Source: Petrovic and Tutsch (2009) and newspaper articles 
board can, moreover, arrange for committees to prepare supervisory board meetings and to take decisions in place of the supervisory board. Particularly important for the banking sector is the implementation of a risk ('Risikoausschuss') and an audit committee ('Prüfungsausschuss'). While the audit committee handles issues of accounting, the independence of the auditor, the issuing of the audit mandate to the auditor, the determination of auditing focal points and the fee agreement, the duty and the responsibility of the risk committee is to control risk management and compliance.

During the recent financial crisis, it has frequently been criticized that the risk committee did not adequately assess the risk management and the risk strategy of German banks. In particular, the role of the supervisory board of public banks is criticized. ${ }^{3}$ Since they are controlled by the federal states, the supervisory boards of public banks often include politicians. This raises questions as to whether government officials may have other interests and may be less motivated to monitor the management than private shareholders. Furthermore, the members of the boards of public sector banks may not be elected based on their experience and skills, but based on their political affiliation. This is demonstrated by Hau and Thum (2009). They analyze how the composition of the supervisory board affects the performance of the 29 largest German banks in 2008. They show that the members of the supervisory board of public sector banks are less educated and less experienced than their counterparts of private banks. Their empirical results, furthermore, suggest that this might have contributed to the large losses of the Landesbanken in the recent crisis.

\section{Corporate Governance Regulation in Germany}

To improve corporate governance the German government enacted several laws in the past years. Most of these laws focus on listed firms. For a list of laws and their main changes see Table 2.

The first law that has significantly improved the corporate governance of German firms was the Law for the Control and Transparency in the Area of Organizations (KonTraG) that came into effect in 1998. The KonTraG has extended the liability of the supervisory board, the management board and the accountants. In addition, it made the use of early warning and risk management systems mandatory for German firms. Further laws to improve corporate governance followed from a catalogue of measures to strengthen the integrity of companies and inves-

3 For example, after the state lending bank KfW had transferred 300 billion euros to Lehman Brothers, just after the bank failed, the Frankfurter Allgemeine Zeitung wrote 'The overseers on the hopelessly bloated 37-member (supervisory) board won't manage to dodge the question of how the bank ran billions and billions of taxpayer euros into the ground' (Spiegel, 2009a). 
tors' protection that was presented by the German government in February 2003. The aim of this so-called ten-point programme was to increase transparency and to improve self-regulation in German firms. The new Law on Award Proceedings (SpruchG) was the first law that followed form this plan. It came into force in September 2003 and deals with a shortening of the legal procedure called ,Spruchverfahren', a legal action which shareholders can file, if they doubt the adequacy of the price they receive for their shares in case of a change of the corporate form or a squeeze-out. The price will then be checked by an auditor appointed by court. In 2004, the Law on the Improvement of Investor Protection (AnSVG), the Law on the Introduction of International Accounting Standards and on the Protection of the Quality of Audits (BilReG) and the Law on Control of Financial Statements (BilKoG) followed.

A further significant step in corporate governance regulation in Germany was the approval the Law on Corporate Integrity and Modernization of Rescission Law (UMAG) by the German Federal Council in July 2005. The UMAG has significantly amended the German Stock Corporation Act (AktG) with regard to directors' potential liability. Further laws that came into force in 2005 were the Law on Capital Market Test Cases (KapMuG) and the Law on the Disclosure of Management Compensation (VorstOG). While the KapMuG has introduced test case litigation for capital market investors who have sustained loss through false, misleading or undisclosed information, the VorstOG is designed to enhance transparency for investors as it obliges stock corporations to individually disclose what their management board members earn. In 2007, investor protection was further improved by the Transparency Directive Implementation Law that has transposed the EU Transparency Directive (2004/109/EC) into German law.

In 2001, the German government additionally appointed a commission to work on essential statutory regulations for the management and supervision of listed companies in 2001. The standards are codified in the German Corporate Governance Code that was adopted by the commission in February 2002. Since then the code has been amended several times. The German Corporate Governance Code aims at making the German corporate governance system more transparent and to promote the trust of international and national investors in the management and supervision of listed German stock corporations. A major problem of the German Corporate Governance Code is that it is not legally binding. However, listed firms are required by Article 161 AktG to declare whether and to which extend they follow the recommendations and suggestions of the code. Furthermore, the 2009 code report indicates that almost 80 percent of the firms 


\section{Table 2: Corporate Governance Legislation up until 2007}

\begin{tabular}{|c|c|}
\hline $\begin{array}{l}\text { Law for the Control and Transparency in the Area of } \\
\text { Organizations (KonTraG) } \\
\text { in force since 01.05.1998 }\end{array}$ & $\begin{array}{l}\text { - } \text { extends the liability of the supervisory board, the management board and the accountants } \\
\text { - makes early warning and risk management systems mandatory }\end{array}$ \\
\hline $\begin{array}{l}\text { Law on Award Proceedings (SpruchG) } \\
\text { in force since } 01.09 .2004\end{array}$ & $\begin{array}{l}\text { - shortens the legal procedure called ,Spruchverfahren' if shareholders doubt the adequacy of the price they receive } \\
\text { for their shares in case of a change of the corporate form or a squeeze-out } \\
\text { - the adequacy of the price will then be checked by an auditor appointed by court }\end{array}$ \\
\hline $\begin{array}{l}\text { Law on the Improvement of Investor Protection } \\
\text { (AnSVG) } \\
\text { in force since } 21.04 .2004\end{array}$ & $\begin{array}{l}\text { - } \text { strengthens insider trading law } \\
\text { - } \quad \text { introduces better measures against market malpractices }\end{array}$ \\
\hline $\begin{array}{l}\text { Law on the Introduction of International Accounting } \\
\text { Standards and on the Protection of the Quality of Au- } \\
\text { dits (BilReG) } \\
\text { in force since 10.12.2004 }\end{array}$ & $\begin{array}{l}\text { - } \text { introduces IFRS accounting standards } \\
\text { - } \text { strengthens the independence of the auditor }\end{array}$ \\
\hline $\begin{array}{l}\text { Law on Control of Financial Statements (BilKoG) } \\
\text { in force since } 21.12 .2004\end{array}$ & $\begin{array}{l}\text { - establishes the Financial Reporting Enforcement Panel (FFEP) as an independent enforcement authority to examine } \\
\text { - financial statements } \\
\text { - } \text { allows the FFEP to take appropriate steps to enforce necessary corrections of accounting irregularities }\end{array}$ \\
\hline $\begin{array}{l}\text { Law on Corporate Integrity and Modernization of Re- } \\
\text { scission Law (UMAG) } \\
\text { in force since } 01.11 .2005\end{array}$ & $\begin{array}{l}\text { - -introduces the business judgement rule as the new standard for the liability of the members of the management } \\
\text { boardvis-à-vis the company } \\
\text { - -makes it easier for minority shareholders to bring liability claims against members of the management board and } \\
\text { the advisory board } \\
\text { - -makes it more difficult to bring abusive claims by shareholders which aim to set aside shareholders' resolutions } \\
\text { - -makes it easier to impose limits on the shareholders' right to speak or to ask questions during the shareholders' } \\
\text { meeting }\end{array}$ \\
\hline $\begin{array}{l}\text { Law on Capital Market Test Cases (KapMuG) } \\
\text { in force since 20.09.2005 }\end{array}$ & $\begin{array}{l}\text { - makes group litigation possible } \\
\text { - introduces the possibility of test case litigation to establish whether market information were falsely given } \\
\text { - } \text { or suppressed }\end{array}$ \\
\hline $\begin{array}{l}\text { Law on the Disclosure of Management Compensation } \\
\text { (VorstOG) } \\
\text { in force since 11.08.2005 }\end{array}$ & $\begin{array}{l}\text { - obliges stock corporations to individually disclose what their management board members earn } \\
\text { - } \text { allows shareholders a company to opt out of disclosure of individual management board remuneration if they have } \\
\text { at least a three-quarter majority at the general meeting. }\end{array}$ \\
\hline $\begin{array}{l}\text { Transparency Directive Implementation Law (TUG) } \\
\text { in force since 20.01.2007 }\end{array}$ & $\begin{array}{l}\text { - requires the management board of listed firms to confirm the balance sheet ('Bilanzeid') } \\
\text { - introduces new share ownership notification rules }\end{array}$ \\
\hline
\end{tabular}

Source: KPMG (2009) and DSW (2009) 
listed in the DAX, Germany's leading stock market index, apply the code (von Werder and Talaulicar, 2009). Including smaller market segments (TecDax, MDAX and SDAX), more than 70 percent of the listed firms abide by the rules of the German Corporate Governance Code. However, the report also indicates that while firms listed in the DAX have almost fully implemented the recommendations and suggestions made by the commission, stock corporations listed in smaller market segments tend to deviate more often from certain regulations of the code.

\section{Anti-Crisis Measur es in Corporate Governance in 2008 and 2009}

In response to the financial crisis several initiatives to improve corporate governance in the German banking sector were started in the past two years. In line with a recent OECD report (Kirkpatrick, 2009) the legislative and regulatory changes mainly focus on reducing the incentives for banks managers to increase short-term profits and on further professionalizing the supervisory board. ${ }^{4}$ For an overview over the main anti-crisis measures of the German government see Box 1.

The first major initiative was to amend the German Corporate Governance Code. The amendments aim at strengthening the incentives for sustainable corporate governance. The focus on sustainability is illustrated in Article 4.1 of the code. While the management board was previously only 'responsible for managing the enterprise independently', the management board is now not only recommended to manage the company independently, but also 'with the objective of sustainable creation of value and in the interest of the enterprise'. The amendments have also brought several changes that affect the remuneration of the management board. While it was previously allowed that special board committees decide on the remuneration of the management board, the revised version of the German Corporate Governance Code recommends that the full supervisory board determines the compensation of individual management board members (Article 4.2.2). The compensation structure shall, furthermore, 'be oriented toward sustainable growth of the enterprise'. The supervisory board shall also make sure that the variable compensation elements are based on a multiyear assessment with both positive and negative developments be taken into account when determining the variable compensation components. All compensation components must, moreover, be appropriate, both individually and in total, and should not encourage taking unreasonable risks (Article 4.2.3).

4 The focus on manager remuneration is illustrated by a statement of the Former Finance Minister of Germany, Peer Steinbrück. In August 2009, he noted that 'There shouldn't be any more excessive pay and false incentives for exaggerated risk. So it's right for banking regulators to be putting the spotlight on payment rules' (Spiegel, 2009b). 
To further professionalize the supervisory board, the revised version of the governance code, moreover, requires that the chairman of the audit committee 'shall have specialist knowledge and experience in the application of accounting principles and internal control processes' (Article 5.3.2). The committee that prepares for nominations of members of the supervisory board shall also be composed of members who have the required knowledge, abilities and expert experience to properly complete their tasks (Article 5.4). Furthermore, to increase the independence of the supervisory board the code now includes a passage that the member of the management board 'may not become members of the supervisory board of the company within two years after the end of their appointment unless they are appointed upon a motion presented by shareholders holding more than 25 percent of the voting rights in the company' (Article 5.4.4).

The second major initiative to improve corporate governance in the German banking sector was the introduction of new Minimum Requirements for Risk Management (MaRisk). MaRisk was introduced in 2005 to implement the second pillar of Basel II in Germany. It sets forth basic principles for risk management. The principle-based character of MaRisk should give banks scope to tailor the implementation to their own particular situation. Banks and financial services institutions are required to implement the new MaRisk by the end of December 2009. The new MaRisk incorporates the recommendations of the Draghi report that was prepared by the Financial Stability Forum (2008) and has changed the current regulation in three important dimensions.

First of all, the revised MaRisk introduces tougher and more wide-ranging supervisory requirements with respect to stress testing, liquidity risk and risk concentration. Important for large banking groups is that the new MaRisk explicitly requires banks to develop a risk strategy for the entire group. While it was previously sufficient to demonstrate that the institution has sufficient risk-bearing capacity at the level of each individual company, it now has to be demonstrated for the group as a whole. The second major change regards bank's remuneration systems. While the remuneration and incentive systems previously did not have to contradict the aims set forth in the bank strategy, incentive schemes must now additionally be structured in a way that any possibility of manipulation is precluded and negative incentives are to be avoided. Remuneration schemes must also ensure that the variable component is based on the long-term performance and also reflects negative business trends. The structure of the incentive systems of individual business units should, moreover, take account of the overall bank performance. The third major change aims at further professionalizing the supervisory board. The new MaRisk, for example, makes a remuneration 


\section{Table 3: Corporate Governance Legislation and Banking Regulation in 2008 and 2009}

\begin{tabular}{|c|c|}
\hline \multicolumn{2}{|c|}{ 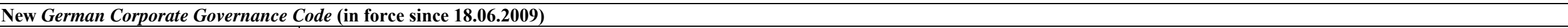 } \\
\hline $\begin{array}{l}\text { Cooperation between Management } \\
\text { Board and Supervisory Board }\end{array}$ & $\begin{array}{l}\text { - The management board and supervisory board have to report each year on the enterprise's corporate governance in the Annual Report and to explain possible } \\
\text { deviations from the recommendations of the German Corporate Governance Code. }\end{array}$ \\
\hline Management Board & $\begin{array}{l}\text { - The management board should manage the enterprise with the objective of sustainable creation of value and in the interest of the enterprise and its stakeholders. } \\
\text { - The full supervisory board determines the total compensation of the management board members and shall resolve and regularly review the compensation system. } \\
\text { - Compensation of the management board should be appropriate in terms of his personal performance, the performance of the enterprise and the common level of } \\
\text { compensation in the industry. } \\
\text { - The supervisory board must make sure that the variable compensation elements are based on a multi-year assessment with positive and negative developments be } \\
\text { taken into account when determining variable compensation components. }\end{array}$ \\
\hline Supervisory Board & $\begin{array}{l}\text { - The supervisory board can delegate preparations for the appointment of members of the management board to a committee, which also deals with the conditions of } \\
\text { the employment contracts including compensation. } \\
\text { - The chairman of the audit committee shall be independent and have specialist knowledge and experience in the application of accounting principles and internal } \\
\text { control processes. } \\
\text { - Management board members may not become members of the supervisory board within two years after the end of their appointment unless they are appointed } \\
\text { upon a motion presented by shareholders holding more than } 25 \text { percent of the voting rights. } \\
\text { - Members of the management board of listed firms shall not accept more than a total of three supervisory board mandates in non-group listed companies. }\end{array}$ \\
\hline \multicolumn{2}{|c|}{ 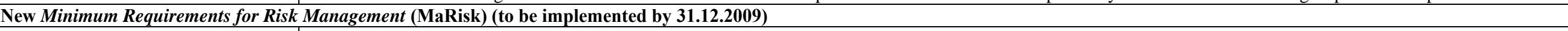 } \\
\hline Risk-Bearing Capacity & $\begin{array}{l}\text { - } \text { stronger emphasis on process character } \\
\text { - } \quad \text { inclusion of all material risks in risk-bearing capacity analysis, using qualified expert assessment if necessary }\end{array}$ \\
\hline Risk Concentrations & $\begin{array}{l}\text { - } \text { stronger emphasis on proper management } \\
\text { - } \quad \text { clear statement that all risk concentrations associated with material risk have to be duly taken into account } \\
\text { - } \quad \text { assessment to risk concentrations associated with counterparty credit risk is to be based - where possible - on quantitative procedures, too }\end{array}$ \\
\hline Stress Tests & $\begin{array}{l}\text { - Hypothetical events will be used alongside historical events to represent exceptional but plausible events in stress tests. } \\
\text { _- Clarifications: stress test results are also to be given due consideration when assessing the risk-bearing capacitv. }\end{array}$ \\
\hline Liquidity Risk & $\begin{array}{l}\text { - regular performance of adequate stress tests over time horizons of varying length } \\
\text { - development of contingency plans and regular review of underlying contingency measures } \\
\text { - extended liquidity risk reporting requirements }\end{array}$ \\
\hline $\begin{array}{l}\text { Interest Rate Risks in the Banking } \\
\text { Book }\end{array}$ & - ban on inclusion of undated own funds components in the present-value calculation of interest rate risk \\
\hline $\begin{array}{l}\text { Consolidated Group-Level Risk Man- } \\
\text { agement }\end{array}$ & $\begin{array}{l}\text {-existing consolidated group risk management requirements amended to clearly define the requirements to be met by superordinated enterprises pursuant to section } \\
\text { 25a (1a) of the German Banking Act and transferred to a module of their own }\end{array}$ \\
\hline Compensation Systems & $\begin{array}{l}\text { - variable compensation for staff members in risk-relevant positions should take due account of the risk taken } \\
\text { - The level of variable compensation should also properly reflect future negative business trends }\end{array}$ \\
\hline Technology and Organisation & - When issuing IT authorisations, care should be taken that members of staff only have those rights actually needed for their activity. \\
\hline $\begin{array}{l}\text { Organisational and Operational Struc- } \\
\text { ture of Lending Business }\end{array}$ & $\begin{array}{l}\text { - Processing principles need to be formulated individually for transactions with hedge funds and private equity firms, too. } \\
\text { - } \quad \text { The exclusive use of external credit assessment is no longer an adequate basis for lending decisions. }\end{array}$ \\
\hline $\begin{array}{l}\text { Organisational and Operational Struc- } \\
\text { ture of trading business }\end{array}$ & $\begin{array}{l}\text { - } \text { - Requirements for processes in trading business amended to include clause stipulating the intra-group transactions, too, can only be conducted on the basis of clear } \\
\text { rules. } \\
\text { - -verification of foreign business }\end{array}$ \\
\hline
\end{tabular}

Source: KPMG (2009), DSW (2009) and Deutsche Bundesbank (2009c) 
committee mandatory for German banks and requires the management board to inform the head of the supervisory board about the remuneration systems. In addition, the management board has to report the supervisory board at least once a year on all severe problems that were identified during the internal audit and on all problems which have not yet been remedied.

Table 3 summarizes the main changes to the German Corporate Governance Code and MaRisk. Other laws that were enacted in 2008 and 2009 to improve corporate governance are the Accounting Law Reform Act (BilMoG) and the Act on Implementing the Shareholders' Rights Directive. The BilMoG transposes the Directive on Statutory Audits of Annual Accounts and Consolidated Accounts (2006/43/EC) and the amending Directive (2006/46/EC) into German law, while the Act on Implementing the Shareholders' Rights Directive (TUG) implements the European Shareholders' Directive (2007/36/EC). The BilMoG makes some recommendations of the German Corporate Governance Code legally binding for capital-market oriented firms. Companies that have not yet established an audit committee as recommended by the code are, for instance, from now on legally required to do. The BilMoG, furthermore, makes it mandatory to have at least one independent financial expert in the audit committee. In contrast to the BilMoG and the TUG that were enacted to implement certain EU directives into German law, the Law on the Appropriateness of Executive Remuneration (VorstAG) was enacted in response to the crisis. It requires the introduction of an extended assessment basis for executive remuneration as well as options for limiting the variable component of the earnings of executives of listed German firms. ${ }^{5}$

\section{Conclusions}

The recent financial crisis has put the German banking sector under enormous pressure. Banks had to massively write-down bad loans and needed large capital injections to offset their existing write-downs and to prevent a systemic collapse of the German banking system. Besides the macroeconomic drivers like, for example, the expansionary monetary policy in major countries, insufficient risk management and weak corporate governance systems have been identified as the main reasons for the financial crisis.

In Germany, corporate governance is weakened by the three-pillar structure of the German banking system that reduces the power of market for corporate control. Furthermore, the large ownership stake of the government in the German banking sector weakens corporate governance, since government officials may have other interests than private shareholders and may be less motivated to monitor the management.

5 For more information on the changes made by the Accounting Law Reform Act (BilMoG) and the Law on the Appropriateness of Executive Remuneration (VorstAG) see Box 1. 
Politicians may also be less educated and experienced to fulfil their role as monitor of bank managers. This may explain the large losses of public sector banks as compared to private banks in the recent crisis and corresponds to the results of a recent OECD report on corporate governance in the financial sector (Kirkpatrick, 2009). The report identifies adverse incentives created by remuneration schemes together with insufficient monitoring by the supervisory board as one of the main reasons for the financial crisis.

To improve corporate governance the German government has started several initiatives in the past two years. In line with the OECD the legal and regulatory changes mainly focus on improving the risk management of German banks, on reducing the incentives for managers to increase short-term profits created by remuneration schemes and on further professionalizing the supervisory board. To reduce the incentives to take large risks, remuneration schemes for managers must, for example, in future be geared toward long-term performance and also reflect negative business trends, while the supervisory board must, henceforth, include at least one person that has the required knowledge, abilities and expert experience to properly fulfil his monitoring tasks. This should particularly improve corporate governance in the public sector where members of the supervisory boards are often based on their political affiliation and not based on their experience and skills. However, given the large number of less educated and inexperienced supervisory board members, the requirement to have only one financial expert in the supervisory board may not be sufficient for public sector banks. Problematic is, furthermore, that the new regulations do not encompass explicit criteria to assess the competence and experience of supervisory board members.

Recent empirical evidence, moreover, suggests that the focus of the legal and regulatory changes on the remuneration of managers is to narrow and falls short of explaining all weaknesses of the German corporate governance system. Fahlenbrach and Stulz (2009), for example, find no evidence that banks with CEOs whose incentives were better aligned with interests of their shareholders performed better during the crisis, but, in contrast, some evidence that these banks performed even worse in terms stock returns and in terms of accounting return-on-equity. This is consistent with a recent paper by Beltratti and Stulz (2009) that shows that banks with more pro-shareholder boards performed worse during the crisis. This suggests that banks were pushed by their boards to increase risk-taking in order maximize shareholder wealth. Gropp and Köhler (2010) get the same result. They find that bank shareholders pushed managers to increase risk-taking. This contrasts with the public view that the managers are responsible for the crisis and pushed by remunerations schemes to increase risk-taking.

Another problem is that several laws that were enacted in the past years to improve corporate governance focus on listed firms only. Furthermore, the recommendations 
and suggestions made by the German Corporate Governance Code are not legally binding even for stock corporations. The latter should be particularly relevant for smaller credit institutions and for banks that are not listed, since the large banks that are listed on the DAX (i.e. Commerzbank/Dresdner Bank, Deutsche Bank) usually almost fully implemented the recommendations and suggestions made by the governance commission. In particular, most Landesbanken have so far abstained from applying the code and enacted their own corporate governance guidelines. This reduces the comparability and transparency of corporate governance standards in particular in those banks that have shown the biggest corporate governance problems in the German banking sector during the recent financial crisis. This suggests that the recent changes fail to remove all weaknesses of the German corporate governance system. 


\section{Literature}

Beltratti, A. and R. M. Stulz (2009), Why Did Some Banks Perform Better During the Credit Crisis? A Cross-Country Study of the Impact of Governance and Regulation, NBER Working Paper Series, No. 15180.

Caprio. G, L. Laeven and R. Levine (2007), Bank Valuation and Corporate Governance, Journal of Financial Intermediation, Vol. 1(4), pp. 584-617.

EU Commission (2005), Cross-Border Consolidation in the EU Financial Sector, Commission Staff Working Document.

Deutsche Bundesbank (2009a), Financial Stability Review 2009.

Deutsche Bundesbank (2009b), Statistics on Principal Assets and Liabilities of Banks in Germany, downloaded from the website of the Bundesbank on December 1st, 2009.

Deutsche Bundesbank (2009c), Amendments to the New EU Capital Requirements Directive and the Minimum Requirements for Risk Management, Monthly Report September 2009.

DSW (2009), Information on Corporate Governance Legislation in Germany provided on the website of the German Association of Private Investors (Deutsche Schutzvereinigung für Wertpapierbesitz), http://www.dsw-info.de/GermanCorporate-Governance- an.594.0.html.

Fahlenbrach, R. and R. M. Stulz (2009), Bank CEOS Incentives and the Credit Crisis, NBER Working Paper Series, No. 15212.

Financial Stability Forum (2008), Report of the Financial Stability Forum on Enhancing Market and Institutional Resilience (Draghi Report).

Gropp, R. and M. Köhler (2010), Bank Owners or Bank Managers: Who is Keen on Risk? Evidence from the Financial Crisis, unpublished Working Paper, Centre for European Economic Research.

Hau, H. and M. Thum (2009), Subprime Crisis and Board (In-)Competence: Private vs. Public Sector Banks in Germany, Economic Policy, Vol. 24, pp. 701-752.

Jensen, M. C. and W. H. Meckling (1976), Theory of the firm: Managerial behaviour, agency costs and ownership structure, Journal of Financial Economics, Vol. 3, pp. 305-360.

Jensen, M. C. and R. S. Ruback (1983), The Market for Corporate Control: The Scientific Evidence, Journal of Financial Economics, Vol. 11, pp. 5-50.

Kirkpatrick, G. (2009), The Corporate Governance Lessons from the Financial Crisis, Report of the Organization for Economic Co-Operation and Development. 
Köhler, M. (2009), Transparency of Regulation and Cross-Border Bank Mergers, International Journal of Central Banking, Vol. 5, pp. 39-74.

KPMG (2009), Information on Corporate Governance Legislation in Germany provided on the website of KPMG's Audit Committee Institute, http://www.audit-committee-institute.de/knowledge/14113_13650.htm.

Levine, R. (2004), The Corporate Governance of Banks: A Concise Discussion of Concepts and Evidence, World Bank Policy Research Working Paper, No.3404.

Manne, H. G, (1965), Mergers and the Market for Corporate Control, Journal of Political Economy, Vol. 73 (2), pp. 110-120.

Petrovic, A. and R. Tutsch (2009), National Rescue Measures in Response to the Current Financial Crisis, Legal Working Paper Series, No. 8, European Central Bank.

Prowse, S. D. (1995), Alternative Methods of Corporate Control in Commercial Banks, Federal Reserve Bank of Dallas Economic Policy Review Economic Policy Review, Third Quarter, pp. 24-36.

Sapienza, P. (2007), The Effects of Government Ownership on Bank Lending, Journal of Financial Economics, Vol. 72, pp. 357-384.

Shleifer, A. and R. Vishny (1986), Large Shareholders and Corporate Control, Journal of Political Economy, Vol. 94(3), pp. 461-488.

Shleifer, A. and R. Vishny (1997), A survey on corporate governance, Journal of Finance, Vol. 52 (2), pp. 737-781.

Shleifer, A. and R. Vishny (1998), The Grabbing Hand: Government Pathologies and their Cures, Cambridge, MA: Harvard University Press.

Spiegel (2009a), Comment of the Frankfurter Allgemeine Zeitung printed in the Article 'Certain Mistakes Just Can't Be Allowed to Happen' of the German News Magazine Spiegel, August 18th, 2009.

Spiegel (2009b), Statement of Peer Steinbrück cited in the Article 'Europe launches Major Push for New Banker Bonus Rules' of the German News Magazine Spiegel, August 8th, 2009.

von Werder, A. and T. Talaulicar (2009), Kodex Report 2009: Die Akzeptanz der Empfehlungen und Anregungen des Deutschen Corporate Governance Kodex, Der Betrieb, Vol. 14, pp. 689-696. 